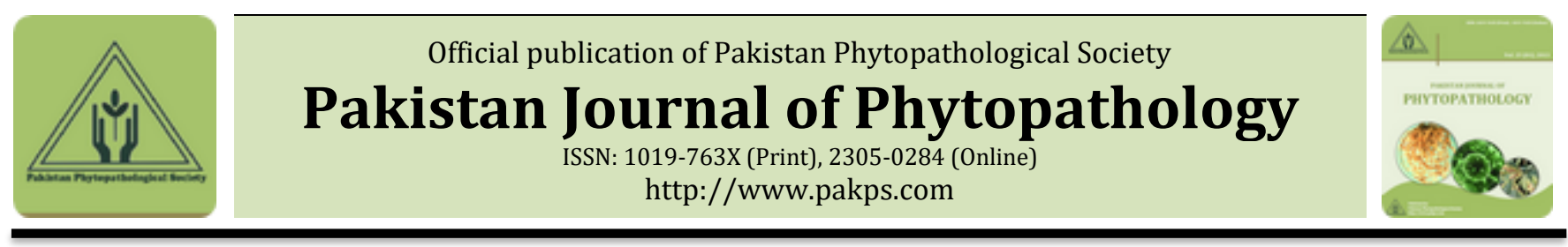

\title{
DIEBACK OF CASHEW (ANACARDIUM OCCIDENTALE) IN CAMEROON
}

\author{
${ }^{a}$ Ngoh D. J. Patrice*, bHeu Alain, cKone N. A. Nourou, dMboussi S. Bertrand, aAsta D. B. Christine, \\ eTchoupou T. D. Brice, fAmbang Zachee \\ a Department of Biological Sciences, Faculty of Science, University of Maroua, PO Box 814 Maroua, Cameroon. \\ ${ }^{b}$ Higher Technical Teacher's Training College, Department of Agriculture and Agropastoral Po Box 886 Ebolowa. \\ c University of Dschang, Department of Plant Biology, Applied Botanic Research Unit, Po Box 67 Dschang. \\ d University of Douala, Laboratory of Plant Biology Po Box 2701. \\ ${ }^{e}$ Higher National Polytechnic School of Maroua, University of Maroua, PO Box 1450 Maroua.

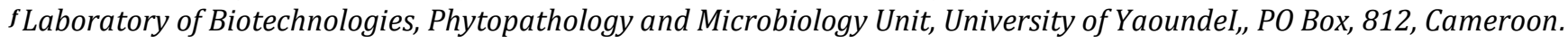

A B S T R A C T

Cashew nut (Anacardium occidentale) is one of the most important cash crops of Far north Cameroon. A disease, named dieback was observed causing serious damage on many trees in some orchards of two mains production sites Maroua and Yagoua. Leaves and stems with symptoms of each attacked tree varieties were randomly extracted for isolation and identification of pathogens. The pathogen structures were characterized under light microscope. Incidence, severity and prevalence of disease were evaluated during the dry and rainy seasons. Pathogenicity test were performed with C. gloeosporioides conidia inoculation of healthy plants. The disease symptoms were first observed in leaves and on bark of stems. Orange brown necrosis were observed in leaves and stem of bark were dark. Both two symptoms lead to death of plant. Different gum exudations were observed on bark of infected trees. Lasiodiplodia spp and Colletotrichum gloeosporioides were identified using identification keys. Young conidia of Lasiodiplodia were hyaline and non-septate, whereas mature conidia were brown, one septate, and striate. Pure culture of C. gloeosporioides is whitish in PDA medium. The disease seems to occur throughout the year, but it spreads faster during the rainy season. Incidence was higher in Yagoua site, 73 and $90 \%$ respectively in dry season and rainy season. Severity was low whatever the site. Artificially inoculated plants (with C. gloesporioides) showed symptoms similar to those that were naturally infected. Yellow variety was more susceptible than red variety. Cashew dieback is spreading to all production areas in the Far North of Cameroon and remains a threat to cashew nut production by reducing tree growth and eventually cause plant death.

Keywords: Anacardium occidentale, dieback, C. gloeosporiodes, Lasiodiplodia sp, incidence, severity

\section{INTRODUCTION}

With the need to respond to new challenges linked to the socio-economic crisis that has affected Africa in recent years, African agriculture has to produce new crops, perennial or annual, food and/or energetic. In most developing countries, agriculture employs $70 \%$ of the workforce and provides between 20 and $60 \%$ of gross domestic product (GDP), and contributes between 10

Submitted: November 13, 2020

Revised: December 15, 2020

Accepted for Publication: December 16, 2020

* Corresponding Author:

Email: ndjuliopat@yahoo.fr

(C) 2017 Pak. J. Phytopathol. All rights reserved. and $90 \%$ of exportation of goods (Didier, 2001).

In the three northern regions of Cameroon, Adamawa, the North and the Far North, cotton is, and remains, the only cash crop. Thus in 1975, the Cameroonian state introduced cashews in the northern region to fight against deforestation by distributing seeds to local populations. Some farmers in the North and Far North region have started to cultivate cashew for its broad ecological spectrum and to associate it with vegetable and food crops (Noiha et al., 2017).

In Far North Cameroon, many projects are underway to expand cashew production. However, many orchards associated with mango trees belong to rural cultivators. Cashew production represents a new source of income 
for the rural population (Adeniyi et al.,2019; Diaz et al., 2003).

The cashew tree is very exported for its cashew nuts whose almond, rich in phenol, oil and sugars, is used in the food industry (Lautié et al., 2001). It is also cultivated for the apple (cashew apple) which contains a sweet, acidic and astringent juice. This apple is directly transformed into juice, wine, syrup or beer in Burkina Faso, Senegal and Ivory Coast (Afouda et al., 2013)

However, many problems are found in the chain of production of this crop, such as diseases caused by microorganisms, which in many cases are limiting their commercial exploitation (Assenga et al., 2020 ; Viana et al., 2007). Among these diseases, dieback is a common one in cashew orchads. Dieback is a disease which attacked many plant species in many countries like cocoa trees in Cameroon (Mvondo et al., 2018; Mbenoun et al. 2007), mango trees in Burkina Faso, Togo and Pakistan (Dianda et al.2018; Tedihou et al., 2017; Kazmi et al., 2005), citrus (Tedihou et al., 2017), cashew in Brasil and Nigeria (Cardoso et al. 2002; Hammed and Abedideji, 2008; Cipriano et al. 2014), Fortunella margarita (Lour) and Aquilaria sinensis in Taiwan (Ko and Wang 2004; Fan et al., 2013), and Camelia oleifera in China ( Zhu et al., 2014).

Lasiodiplodia theobrome is the largest causal agent of this disease. Besides, some others fungi species are associated or not with L. theobromae in dieback like Phytophthora citrophthora (Ko et al., 2004). Fusarium oxysporum (Mvondo et al., 2018), Ceratocystis fimbriata (Hassan and Nazzami, 2017; Oliveira et al. 2015) Aspergillus niger, Botritis cineria, Curvularia sp, Fusarium sp and Schizosaccharomyces pombe were also isolated from the stem of trees infected by L. theobrome (Dianda et al., 2018; Mvondo et al., 2018).Gummosis are always found in the bark of the stem of several trees attacked.

In Cameroon, there is lack of data on the dieback disease. However, many projects are underway with the aim of marketing areas for cashew nuts. It is therefore necessary to have knowledge of causal pathogens of dieback cashew tree which cause a reduction in plant photosynthetic surface area because of tissue necrosis, defoliation, and death of plant organs. This work will give a better understanding of fungi organisms involved in the dieback expression and serves as towards fungal decline disease management.

\section{MATERIALS AND METHODS}

Study areas: Samples were collected in Far North Cameroon during two years (2019 and 2020). Divisions of Diamaré and Mayo Danay, which are the only cashew production areas were choosen. Three orchards were surveyed in each of the three localities of the two subdivisions choosen by site. Pathogens isolation and characterization where carry out in Biological Sciences Laboratory of Maroua and Laboratory of Biotechnologies, Phytopathology and Microbiology Unit, of University of Yaounde I.

Experimental design and Collection of samples: The experimental design was completely randomized with three replications in each site. In each Division, a subdivision has been chosen (Maroua and Yagoua) representing our study sites. In each subdivision, three districts have been chosen representing the blocks. In each block, one (01) orchard was chosen at random representing the plots. In each plot, 20 trees of each cashew variety, yellow and red, (10 years old at least)were chosen for sampling and monitoring the progress of the disease. About,sixty (60) trees per study site.

The samples were collected during two years (20192020) in the dry (From march to april) and rainy (july to august) seasons. Far North is characterized by a long dry season and a short rainy season (3 months).

In each orchards, infected samples of organs (leaves and bark of stem), were collected (in morning) on ten trees chosen randomly following the diagonal of each orchard visited. The samples were packaged in plastic bags containing cotton soaked with sterile distilled water and transported in laboratory. Samples were used immediately or were stored at $4^{\circ} \mathrm{C}$.

Pathogens isolation and characterization: Identification of disease was done by observation of symptoms in field in different orchards and compared to identification keys (Nakpalo et al., 2017 ; Wonni et al., 2017; Afouda et al., 2013; Cardosos et al. 2002; Cipriano et al., 2014).

Isolation and identification of pathogen consisting of observation, measurements and description of fungal structures in optical microscope with micrometer. Micrometer was used to measure length and width of fungi conidia (Barnett and Hunter (1986).

Samples cultivation was carried out on Potato Dextrose Agar (PDA; containing g l-1: 200 g potato, $20 \mathrm{~g}$ dextrose, $15 \mathrm{~g}$ agar) and water agar (WA, 
containing $\mathrm{g} \mathrm{l}^{-1}, 15 \mathrm{~g}$ agar) media. Petri dishes of 90 mm were used.

Sections of $1 \mathrm{~cm}$ diameter were cut from leaves with symptoms and stem rotten, using sterilized scalpel. Explants were washed in tap water. Then, sterilized in ethanol $(70 \%)$ firstly for one minute followed by immersion in $1 \%$ of sodium hypochlorite solution for 2 min. The infected section was then washed three times in Sterile Distilled Water (SDW). Sterilized explants were dried and grown on Petri dishes containing WA and PDA medium. Cultures were incubated at $25^{\circ} \mathrm{C}$ on photoperiod $12 / 12 \mathrm{~h}$. After 4 or 7 days, colony growth was hyphal-tip transferred on a new PDA medium to obtain pure cultures and to observed and to describe structures of pathogen.

Mycelial discs of pure culture of $L$. theobromae was transferred on Petri dishes containing PDA with sterilized plant needles and incubated at $25^{\circ} \mathrm{C}$ under continuous light for three weeks at least to enhance sporulation.

Gums with different color have been removed from stem.

Pathogenicity test: Pathogenicity test were performed only with $C$. gloeosporioides. The young cashew seedlings, 3-6 months old and carrying six (06) to eight (08) leaves were cleaned with tap water, alcohol at $70^{\circ}$ $\mathrm{C}$ and then with sodium hypochlorite (1\%) and rinsed with sterile distilled water. For moisture conservation, these plants were closed with transparent plastic bags until the next morning. Three plants have been inoculated for each. Inoculum was prepared from 7 days old pure cultures by flooding plates with $10 \mathrm{~mL}$ sterile distilled water. Conidia were collected with $20 \mathrm{ml}$ sterile syringe and counted in a Malassez haemacytometer. Conidia concentration was adjusted to 4-6 $\times 10^{5}$ conidia $/ \mathrm{ml}$. The conidia suspension $(12.5 \mathrm{ml}$ per plant) was applied on leaves inferior surface with a 20 $\mathrm{ml}$ syringe. Control plants were sprayed with sterilized distilled water. After inoculation, plants were covered with a clear plastic to maintain high humidity and plants were regularly sprayed with water. Koch's postulate was carried out from the organs showing symptoms after infection (Nakpalo et al., 2017; Wonni et al., 2017).

Assessment of disease incidence: Diseases incidence was assessed on twenty trees selected randomly in each orchards. Modified protocol of Shomari and Kennedy (1999) and Afouda et al., (2013) was used. The evaluation was made according to the North, South, East and West sides of the crown (canopy) of each tree. 56 trees were observed by site. Incidence was estimated following the formula :

$$
\mathrm{I}(\%)=\frac{n}{N} \times 100
$$

(Masood et al., 2010). Where $n$ is the number of trees infected by a disease and $\mathrm{N}$, the total number of trees inspected. Data were recorded during dry (marchapril) and rainy (july-august) seasons.

Assessment of disease severity: Severity was assessed by estimating the leaf area occupied by the symptoms of the disease following the formula: $\mathrm{S}=$ $\sum(\mathrm{ab}) / \mathrm{N}$ (Masood et al., 2010). Where $\mathrm{S}$ is the average severity of the disease in the site, $\sum$ is the sum of the products of the number of diseased plants, (a) the severity index, (b) the number of plants with the index given in $\%$ and $\mathrm{N}$ the total number of trees observed. Data were recorded during dry (march-april) and rainy (julyaugust) seasons. The disease severity index was assessed using a visual scale of 0 to 9 (Cooke, 2006. Cardoso et al., 2009; Afouda et al., 2013) :0 = no symptom ; $1=1-4 \% ; 2$ $=5-9 \% ; 3=10-19 \% ; 4=20-29 \% ; 5=30-44 \% ; 6=45-$ $59 \% ; 7=60-75 \% ; 8=76-90 \% ; 9=>91 \%$ percentage of average lesion per leaf infected.

Assessment of the prevalence of the disease: The prevalence assessment was carried out on an average of 40 trees in each variety at the two study sites using the following formula: $\mathrm{P}=\mathrm{n} / \mathrm{N} \times 100$ where $\mathrm{n}$ is the number of tree of the variety affected and $\mathrm{N}$ is the total number of feet of the variety in the site.

\section{STATISTICAL ANALYSIS}

Data of incidence and severity collected, were analyzed using analysis of variance (ANOVA 1 ) one way. $p<0.05$ and averages were compared through Duncan multiple range test with statistical software SPSS 20.0.

\section{RESULTS AND DISCUSSION}

Symptoms of dieback of cashew: Symptoms appear on the leaf tips by necrosis orange-brown in color (Figure $1 \mathrm{a}$ and b). This symptom is attributed to anthracnose. The leaves dry out completely on the attacked branches and eventually fall off and cause the tree to die, in severe cases (Figure $1 \mathrm{c}$ and d), which is then of no further agronomic interest (Figure $1 \mathrm{c}$ and d). When the whole tree is affected, the bark has a burnt appearance and the tree is rotted away. (Fig. 1 e). This disease leads to a physiological dysfunction of the plant that leads to the production of gums (Figure $1 \mathrm{f}$ ) whose aspects vary (Figure $1 \mathrm{~g}$ ). 
This disease is generally present in mixed orchards, i.e. orchards where both cashew and mango trees are present. As both plants are of the same family (cashew trees), it is noted that if the mango plant near the cashew tree is attacked by the decline, then the cashew tree is also attacked.
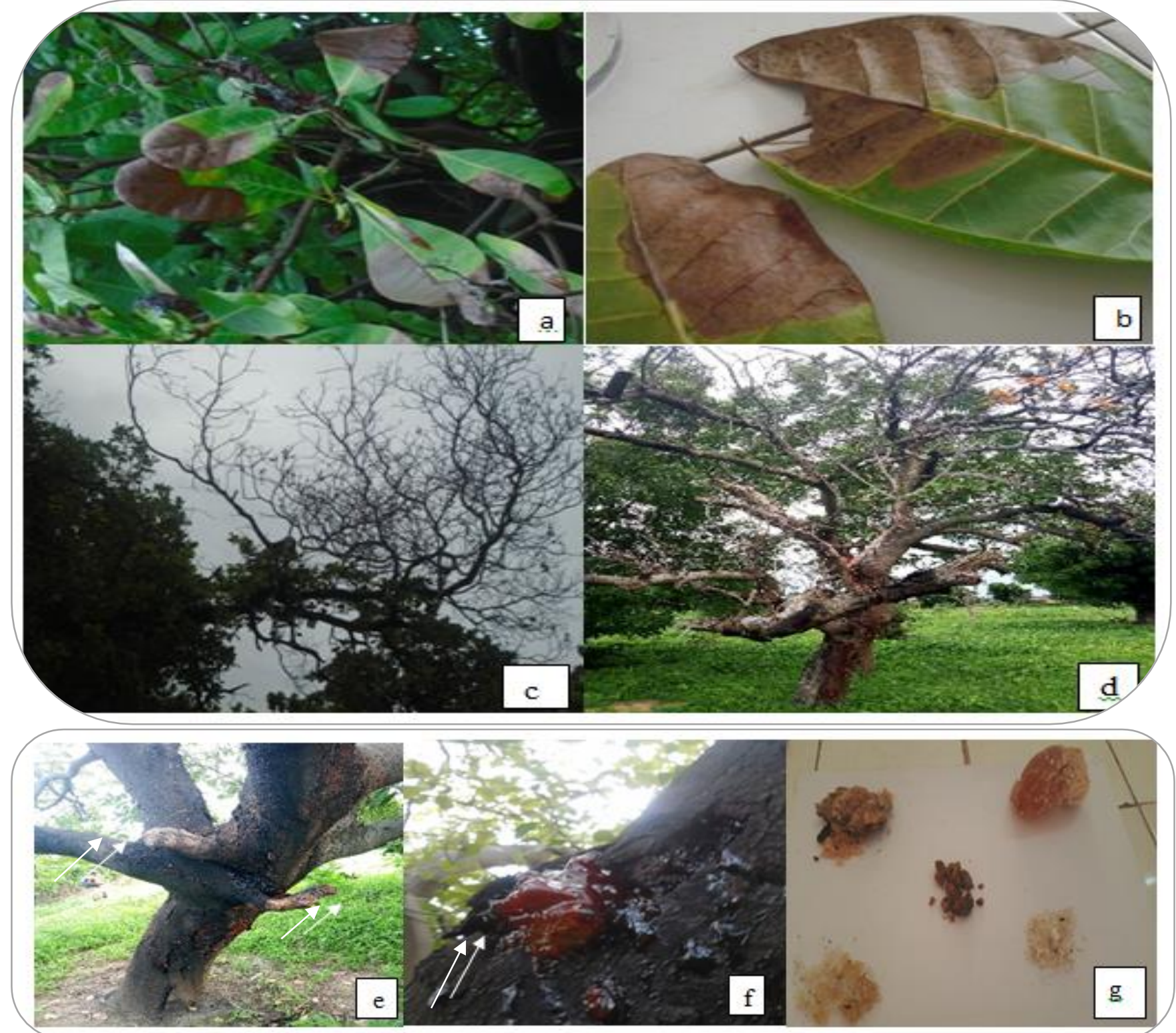

Figure 1. Symptoms of anthracnose and dieback on cashew: necrosis on leaves ( $a$ and b);branches and tree rotted away(c et d) ;blight of stem (e) ; Gum on the bark of stem (f) various gums isolated from different infected trees (g).

Pathogens identified: On the bark of the stems and branches, conidia of ovoid shape with a partition of the species Lasiodiplodia sp were obtained. Young conidia were hyaline and non-septate, whereas mature conidia were brown, one septate, and striate (Figure 2b). The corresponding mycelium is blackish in appearance. (Figure 2a).
On leaves, spindle-shaped and cylindrical conidia of the species C. gloeosporioides were observed (Figure 2d). The pure culture obtained has a whitish color (Figure 2c). The mean length of the cylindrical conidia ranged from 10.33 to $18.07 \mu \mathrm{m}$ and 10.22 to $35.33 \mu \mathrm{m}$ for spindle-shaped conidia. The width of the two conidial forms of C. gloeosporioides ranged from 2.58 to $5.16 \mu \mathrm{m}$. 


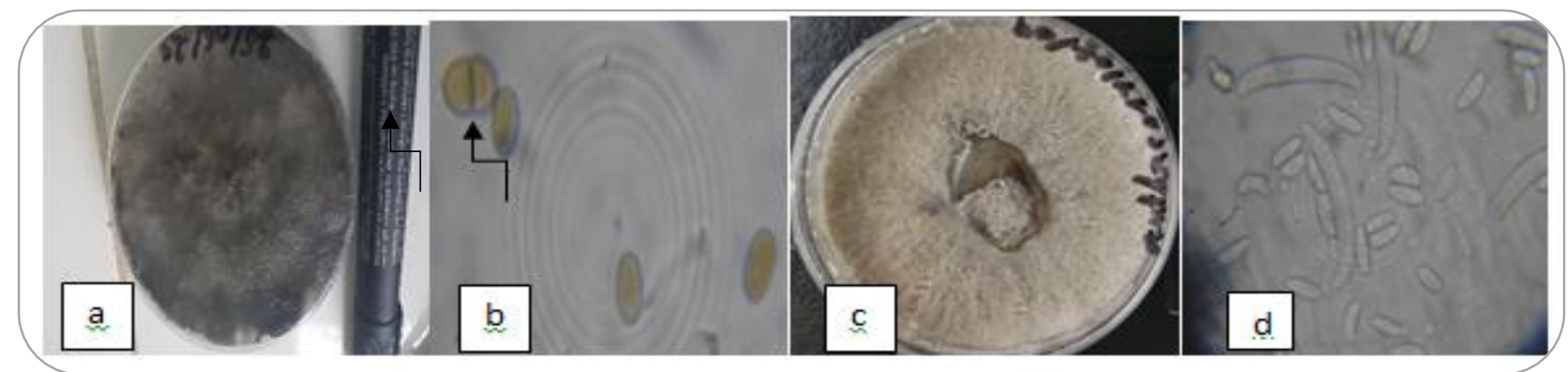

Figure 2. Pure culture (a) and conidia (b) of Lasodiplodia sp. Pure culture (c) and conidia of C. gloeosporioides(d) (x400)

Pathogenicity tests: Pathogenicity tests of $C$. necrotic brownish spot (C. gloeosporioides). The control gloeosporioides showed similar symptoms to those sampled following inoculation (Figure 3 b). After 2weeks, cashew plants inoculated with conidial suspension of selected isolates developed spot on plants, did not develop any symptom (Figure 3 a). The pathogen was re-isolated from infected cashew leaves on PDA to fulfill Koch's postulates. Pathogenicity test with Lasiodiplodia sp spores was not performed.

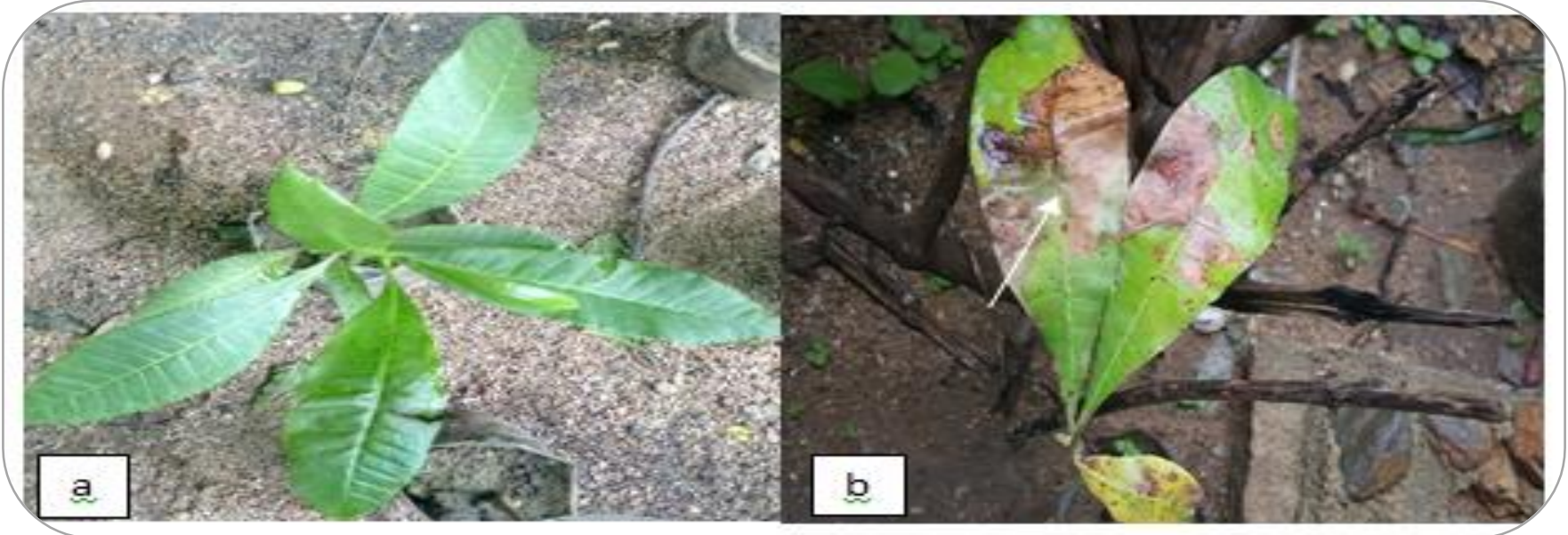

Figure 3. Results of pathogenicity test after two weeks: a) control, b) plant inoculated with conidia of $C$. gloeosporioides

Incidence and severity: A highly significant difference (P $<0.001$ ) was obtained in the evolution of the incidence of dieback in the two sites. The incidence and severity increase with the season. In Yagoua site, incidence rate was $73.3 \pm 1.1$ and $90.00 \pm 0.9 \%$ respectively in dry season and rainy season.
Incidence was $60 \pm 0.6 \%$ in rainy season against $42.5 \pm 0.9$ $\%$ in dry season at Maroua site (Table 1).

The severity remained low $(<30 \%)$ whatever the site and the season, despite the significant difference $(P<0.05)$ obtained in the two sites (Table 1).

Table 1.Incidence and severity (\%) of dieback per production sites and by season

\begin{tabular}{|c|c|c|c|c|}
\hline & \multicolumn{4}{|l|}{ Sites } \\
\hline & \multicolumn{2}{|l|}{ Maroua } & \multicolumn{2}{|l|}{ Yagoua } \\
\hline & Dry season & Rainy season & Dry season & Rainy season \\
\hline Incidence & $42.5 \pm 0.9 \mathrm{a}$ & $60.00 \pm 1.9 \mathrm{~b}$ & $73.33 \pm 1.1 \mathrm{a}$ & $90,00 \pm 0.9 \mathrm{~b}$ \\
\hline Sévérité & $7.29 \pm 0.1 \mathrm{a}$ & $28.73 \pm 0.8 b$ & $17.03 \pm 0.1 \mathrm{a}$ & $26.30 \pm 1.9 \mathrm{~b}$ \\
\hline
\end{tabular}

The mean values followed by the same lower case letters in the rows (in the same site) are not significantly different at the 5\% threshold according to Duncan's test

Prevalence of dieback on cashew varieties: The prevalence of dieback rate is very high for the red (65\%) and yellow (84 \%) varieties in the locality of Yagoua. At Maroua, the prevalence is low in the two varieties, 18.8
$\%$ and $46 \%$ for the yellow and red varieties respectively. The yellow variety seems more susceptible to dieback, but the prevalence rate also seems to depend on the locality (Figure. 4). 


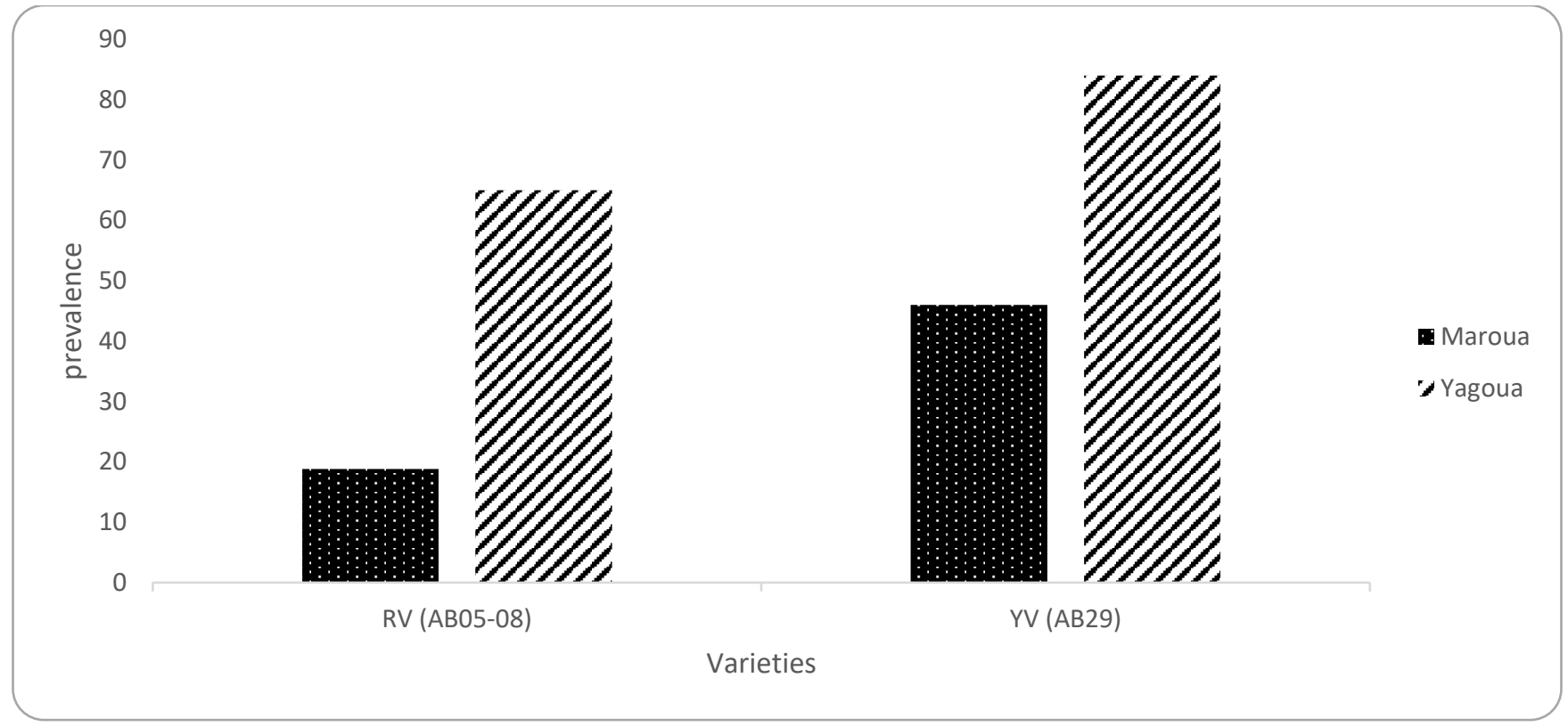

Figure 4. Prevalence of dieback in the two sites. RV (red variety); YV (yellow variety).

\section{DISCUSSION}

Dieback of cashew (Lasiodiplodia theobromae or Colletotrichum sp) has also been reported in Mozambique (Uaciquete, 2013), Côte d'Ivoire (Nakpalo et al., 2017), Benin (Khatoon et al., 2017) and Burkina Faso (Wonni et al., 2017).

Colletotrichum gloeosporioides is the most important disease in cashew orchards all over the world causing anthracnose which leads to drop of leaves (Afouda et al., 2013). On the contrary while Lasiodiplodia theobromae seems to be less important according to some studies it is the main pathogen responsible of inflorescences, gummosis, twigs and shoot dieback in Nigeria, Ivory coast, and in many others countries (Salvatore et al., 2020; Hassan and Nazzami, 2017; Adeniyi et al., 2011; Oliveira et al., 2015; Shah et al., 2010; Masood et al., 2010). Complex of these two fungi is not always reported in dieback literature. However, a complex consisting of Lasiodiplodia theobromae in association with Pestalotia heterocornis was isolated from crack blackened lesions on twig (Cardoso et al., 2000), Association of Lasiodiplodia theobromae, Ceratocystis fimbriata and Phomosus sp was isolated in cashew (Masood et al., 2010). But there was not enough report on the association of this fungus causing gummosis of stem, although an unidentified species of Colletotrichum was reported earlier. In many cases, pathogenicity tests have proved that Lasiodiplodia theobromae is the causal agent of dieback.

The variability of dieback attacks would be linked at the variability of the conditions in the cashew orchards. Dieback disease can occur at any time during the year (dry and rainy seasons), but it is more visible and severe in rainy season.

Dieback appear in all sites surveyed. This could be probably due to climatic conditions which are favorable for the development of the disease. The rainfull in Maroua was1140, $2 \mathrm{~mm}$ and $901 \mathrm{~mm}$ in Yagoua of water. However, Mvondo et al. (2018) have shown that dieback of cocoa is severe in dry season. Furthermore, most farmers lacked knowledge on disease epidemiology and identification, and had limited resources for disease management. Consequently, they do not use any appropriate strategies to control disease.

The type of season is a very important parameter in the process of assessing the evolution of a disease. Afouda et al., (2013) have shown that diseases such as anthracnose and dieback are lower in the dry season compared to the rainy season. This information provides the period of time when arrangements should be made to treat and prevent disease in the field.

Based on the cultural characteristics and conidial morphology of the fungi isolated on stem barks and leaves in different surveyed sites, the pathogens were identified as being probably Lasiodiplodia theobromae and Colletotrichum gloeosporioides. In fact, an important morphological characteristic for the identification of $L$. theobromae is presence of aseptate paraphyses observed in immature pycnidia. This feature was reported in a study, in which aseptate paraphyses along with conidial 
size were the primary morphological characteristics to separate L. theobromae from other Lasiodiplodia found in the tropics (Burgess et al., 2006; Cardoso et al., 2009). Furthermore, the conidia were similar to those described for L. theobromae in shape, color and striation as reported by Punithalingam (1976), Mvondo et al. (2018) and Adeniyi et al. (2016). Conidia morphology of C. gloeosporioides are identical to those described by Nakpalo et al. (2017), Wonni et al. (2017) and Uaciquete et al. (2013). C. gloeosporioides had a length of $10.33 \mu \mathrm{m}$ to $18.07 \mu \mathrm{m}$ and a width of $2.58 \mu \mathrm{m}$ to $5.16 \mu \mathrm{m}$. The size of these conidia was also measured by Nakpalo et al. (2017). They had a length of $13.94 \mu \mathrm{m}$ and a width of $4.81 \mu \mathrm{m}$.

In both study sites, cashew tree dieback was highly prevalent, and the majority of affected cashew tree stems showed gumming, followed by bark burning and even complete tree dieback. Thus, for the majority of the dieback, the orchard owners completely cut off the trees. Despite the large number of trees cut, dieback was highly prevalent $(65 \%$ and $84 \%)$ in Yagoua in both varieties. Similarly, Gnahoua et al. (2003) reported in a study on cashew tree in Côte d'Ivoire that cashew tree dieback caused a lot of damage.

The prevalence of dieback was very high in yellow variety than in red variety. The prevalence of this disease on cashew orchards can partially justify the decrease of cashew yield. Soro (2011) had indicated that work on genotypes could facilitate the selection of cashew varieties.

\section{CONCLUSION}

The cashew dieback seems to be due to the association of Colletotrichum gloeosporioides which leads to necrosis and leaf fall and Lasiodiplodia sp which leads to stem rot. It would be interesting to see the effect of plant age on this phenomenon and perform pathogenicity test with L. theobromae.

\section{REFERENCES}

Adeniyi, D. O., D. A. Animasaun, A. A. Abdulrahman, K. S. Olorunmaiye, G. S. Olahan and O. A. Adeji. 2019. Integrated System for Cashew Disease Management and Yield. Cameroon Journal of Experimental Biology, 13: 40-48.

Adeniyi, D., S. Orisajo, O. Fademi, O. Adenuga and L. Dongo. 2011. Physiological studies of fungi complexes associated with cashew diseases. Journal of Agricultural and Biological Science, 6: 34-38.
Afouda, L., V. Zinsou, R. Balogoun, A. Onzo and B. Ahohuendo. 2013. Inventaire des agents pathogènes de l'anacardier (Anacardium occidentale L.) au Bénin. Bulletin de la Recherche Agronomique du Bénin, 73: 13-19.

Assenga, B. B., P. A. Masawe, T. M. Tarimo, F. Kapinga and E. R. Mbega. 2020. Status of sucking insect pests in cashew growing locations of South and Central Zones, Tanzania. International Journal of Biosciences, 16: 34-45

Barnett, H. L. and B. B. Hunter. 1998. Illustrated genera of imperfect fungi. American Phytopathological Society (APS Press). Pp. 218.

Burgess, T. I., P. A. Barber, S. Mohali, G. Pegg, W. de Beer and M. J. Wingfield. 2006. Three new Lasiodiplodia spp. from the tropics, recognized based on DNA sequence comparisons and morphology. Mycologia, 98: 423-435.

Cardoso, J., J. Vidal, A. d. Santos, F. Freire and F. Viana. 2002. First report of black branch dieback of cashew caused by Lasiodiplodia theobromae in Brazil. Plant Disease, 86: 558558.

Cardoso, J., M. Bezerra, F. Viana, T. de Sousa, A. Cysne and F. Farias. 2009. Endophyte occurrence of Lasiodiplodia theobromae in cashew tissues and its transmission by vegetative propagules. Summa Phytopathologica, 35: 262-266.

Cipriano, A. K., D. M. Gondim, I. M. Vasconcelos, J. A. Martins, A. A. Moura, F. B. Moreno, A. C. Monteiro-Moreira, J. G. Melo, J. E. Cardoso and A. L. S. Paiva. 2015. Proteomic analysis of responsive stem proteins of resistant and susceptible cashew plants after Lasiodiplodia theobromae infection. Journal of proteomics, 113: 90-109.

Cooke, B. 2006. Disease assessment and yield loss, the epidemiology of plant diseases. Springer, pp. 43-80.

Dianda, Z., I. Wonni, C. Zombré, O. Traoré, D. Sérémé, F. Boro, I. Ouédraogo, S. Ouédraogo and P. Sankara. 2018. Prévalence du dessèchement du manguier et evaluation de la fréquence des champignons associés à la maladie au Burkina Faso. Journal of Applied Biosciences, 126: 12686-12699.

Didier, C. 2001. La culture de l'anacardier. 81: 1-3. 
Fan, M.-C., H.-C. Yeh and C.-F. Hong. 2013. First report of Lasiodiplodia theobromae causing dieback of Aquilaria sinensis in Taiwan. Plant disease, 97: 690-690.

Hammed, L. and A. Adedeji. 2008. Incidence and control of Twig die-back in young cashew in Ibadan (South Western Nigeria).Journal of Agriculture, 3: 171-175.

Hassan, Z. U. and N. Nazami. 2017. Potential risk to mango orchards: mango sudden decline caused by Ceratocystis fimbriata. Pakistan Journal of Phytopathology, 29: 181-185.

Kazmi, M., F. Fateh, K. Majeed, A. Kashkhely, I. Hussain, I. Ahmad and A. Jabeen. 2005. Incidence and etiology of mango sudden death phenomenon in Pakistan. Pakistan Journal of Phytopathology, 17: 154-158.

Ko, W., I. Wang and P. Ann. 2004. Lasiodiplodia theobromae as a causal agent of kumquat dieback in Taiwan. Plant disease, 88: 13831383.

Lautié, E., M. Dornier, M. de Souza Filho and M. Reynes. 2001. Les produits de l'anacardier: caractéristiques, voies de valorisation et marchés. Fruits, 56: 235-248.

Masood, A., S. Saeed, N. Iqbal, M. T. Malik and M. R. Kazmi. 2010. Methodology for the evaluation of symptoms severity of mango sudden death syndrome in Pakistan. Pakistan Journal of Botany, 42: 1289-1299.

Mbenoun, M., E. Momo Zeutsa, G. Samuels, F. Nsouga Amougou and S. Nyasse. 2008. Dieback due to Lasiodiplodia theobromae, a new constraint to cocoa production in Cameroon. Plant Pathology, 57: 381-381.

Mvondo Nganti Dorothée, A. Z., Manga Essouma François, Moutock Francis, Kone Nourou and a. N. P. A. Abdou. 2018. Investigation about dieback in cocoa orchards in the bimodal humid forest zone of Cameroon. American Journal of Innovative Research and Applied Sciences, 6: 107-116.

Nakpalo, S., S. Sibirina, K. Tchoa, A. Kouabenan, K. Mongomaké and K. Daouda. 2017. Parasitical fungi in cashew (Anacardium occidentale L.) orchard of Côte d'Ivoire. Pakistan Journal of Phytopathology, 16: 82-88.

Noiha Noumi, V., L. Zapfack, V. Awé Djongmo, N.
Witanou, B. Nyeck, J. Ngossomo, M. Hamadou, C. Chimi and R. Tabue Mbobda. 2017. Floristic structure and sequestration potential of cashew agroecosystems in Africa: A case study from Cameroon. Journal of Sustainable Forestry, 36: 277-288.

Oliveira, L. S., T. C. Harrington, M. A. Ferreira, M. B. Damacena, A. M. Al-Sadi, I. H. Al-Mahmooli and A. C. Alfenas. 2015. Species or genotypes? Reassessment of four recently described species of the Ceratocystis wilt pathogen, Ceratocystis fimbriata, on Mangifera indica. Phytopathology, 105: 1229-1244.

Punithalingam, E. 1976. Botryodiplodia theobromae. [Descriptions of Fungi and Bacteria]. IMI Descriptions of Fungi and Bacteria. pp 519.

Salvatore, M. M., A. Alves and A. Andolfi. 2020. Secondary metabolites of Lasiodiplodia theobromae: Distribution, chemical diversity, bioactivity, and implications of their occurrence. Toxins, 12: 457.

Soro, D., F.A.P. Abreu, E. Assidjo,B. Yao, M. Dornier and M.Reynes. 2011. The cashew (Anacardium occidentale, L.) industry in Ivory Coast Analysis and prospects for development. Fruits, 66: 4-9.

Tedihou, E., K. Kpemoua and A. Tounou. 2017. Dépérissement des manguiers et citrus dans la région centrale du Togo et méthodes de lutte par des fongicides. Journal of Applied Biosciences, 119: 11829-11838.

Uaciquete, A. 2013. Characterization, epidemiology and control strategies for the anthracnose pathogen (Colletotrichum spp.) on cashew (Anarcardium occidentale L.) in Mozambique. University of Pretoria. pp.85.

Uaciquete, A. 2013. Characterization, epidemiology and control strategies for the anthracnose pathogen (Colletotrichum spp.) on cashew (Anarcardium occidentale L.) in Mozambique. University of Pretoria.Crop Protection, 49: 6672.

Viana, F., J. Cardoso, H. Saraiva, M. Ferreira, R. Mariano and L. Trindade. 2007. First report of a bacterial leaf and fruit spot of cashew nut (Anacardium occidentale) caused by Xanthomonas campestris pv. mangiferaeindicae in Brazil. Plant disease, 91: 1361-1361. 
Wonni, I., D. Sereme, I. Ouedraogo, A. Kassankagno, I. Dao, L. Ouedraogo and S. Nacro. 2017. Diseases of cashew nut plants (Anacardium Occidentale L.) in Burkina Faso. Advances in Plants Agriculture Research, 6: 00216.
Zhu, H., X.-Q. Niu, W.-W. Song, F.-Y. Yu, Q.-H. Tang, W.-Q. Qin and L.-Q. Chen. 2014. First report of leaf spot of tea oil Camellia (Camellia oleifera) caused by Lasiodiplodia theobromae in China. Plant Disease, 98: 1427-1427.

\section{Contribution of Authors:}

Ngoh D. J. Patrice

Heu Alain

Kone N. A. Nourou

Mboussi S. Bertrand

Asta D. B. Christine

Tchoupou T. D. Brice

Ambang Zachee
: Designed the experiment wrote the manuscript

: Prepared figures

: Designed the experiment

: Performed the experiment

: Analyzed the data

: Edit the manuscript

: Analyze the data 